\title{
Creative-Critical Thinking Stimulation of Pre Service Teachers by Socratic Questions and Chemical Representation
}

\author{
Abdul Hamid ${ }^{1,2}$ \\ ${ }^{1}$ Chemistry Education Study Program \\ Faculty of Teacher Training and Education \\ Universitas Lambung Mangkurat \\ Banjarmasin, Indonesia \\ ahamid_kimia@unlam.ac.id \\ ${ }^{2}$ Doctoral Program of Science Education \\ Faculty of Teacher Training and Education \\ Universitas Negeri Sebelas Maret \\ Surakarta, Indonesia \\ hamidkimia123@student.uns.ac.id
}

\begin{abstract}
Creative-critical thinking skills are two things that are inseparable. Critical-creative thinking skill is a skill demanded in the 21st century to survive in facing the world change. Creative-critical thinking skill is very important for pre service teachers. This will affect the ability to think of their students, especially in terms of processing, assessing, taking information, and making decisions. Creative thinking skill in the learning process can be stimulated by using Socrates' questions because chemistry is closely related to life problems while thinking creatively uses chemical representation. Socrates questions and chemical representations can be implemented simultaneously in the learning process. Chemical concepts are generally abstract, so they need to be comprehensively or comprehensively understood. The chemical concept is between phenomenology, abstraction, macroscopic, and microscopic so that a bridge is needed through chemical representation. Chemical representation has the meaning of recalling the mind through images or imagination or symbolizing in an explanation. The purpose of this literature review is to describe the importance of questions of Socrates and chemical representation to stimulate the creative-critical thinking skills of chemistry teacher pre service. Based on this review, it is concluded that socratic question and chemical representation can stimulate creative- critical thinking skill of chemistry pre service teachers.
\end{abstract}

Keywords-stimulation, socrates' questions, chemical representation, creative-critical thinking

\section{INTRODUCTION}

Critical and creative thinking skills are skills demanded in the 21 st century in order to survive in the face of an everchanging world. Creative-critical thinking skills are two things that are inseparable. Critical and creative thinking skills sharpen each other. According to Ref. [1] critical and creative thinking skills function in an alternating step indefinitely, when solving problems, logical and analytical thinking (critical thinking) occurs first followed by the growth of a large number of creative thinking. Then, the idea or assessment is evaluated (critical thinking) to get the best solution.

Ref. [2] states that the core of critical thinking is a detailed description of a number of characteristics which include interpretation, analysis, inference, explanation, evaluation, and self-regulation, Meanwhile, Runco's creative thinking skills are fulfilling four components, namely: (1) fluency is the ability to produce a number of ideas, (2) originality is the ability to produce unique ideas out of habit, (3) flexibility is the ability to produce diverse ideas, and (4) elaboration is the ability to develop or issue an idea.

Creative-critical thinking skills are very important for pre service teachers. These skills will affect the thinking ability of their students, especially in terms of processing, evaluating, taking information, and making decisions. Creative-critical thinking skills need to be developed by stimulating these skills. Critical thinking skill uses social questions, and creative thinking skill uses chemical representations through Jonstone thinking levels. The questions of socrates and chemical representations in the chemistry learning process of implementation are inseparably complementary to each other so that more studies are needed.

\section{METHOD}

This study used an analytical descriptive method focusing on the main problem in the study of creative-critical thinking in chemistry. The type of this study used was library studies or literature review, namely by collecting various journals, references, and books on creative-critical thinking and chemical representation. Data collection was done by reading, studying, and analyzing the content of reading sources with the content approach. A literature study was done by finding the relevant theory to the issues discussed. 


\section{RESULTS AND DISCUSSION}

\section{A. Chemistry and Socrates Questions}

Chemistry is developed based on experiments that seek answers of the questions what, why and how about natural phenomena; specifically related to changes in the composition, structure of properties, transformation, dynamics, and energetics of a substance. Chemistry is very closely related in life, so something related to chemistry can be seen and experienced by individuals every day [3]. This condition can be used to stimulate critical thinking of pre service chemistry teacher through socrates questions. Socrates questions are learning strategies to encourage discussion in order to develop and evaluate thoughts to explain problems and find solutions.

The Socrates question according to Ref. [4] is categorized in 3 forms namely; spontaneous questions, exploratory, and specific questions. Spontaneous questions are asked spontaneously asking what is meant by the explanation of prospective teacher students, exploratory questions to find out what students think or know, and specific questions to know or investigate deeper thought processes. The type of question socrates can be seen in Table 1.

TABLE I.

TYPES OF QUESTIONS [4]

\begin{tabular}{|l|l|}
\hline \multicolumn{1}{|c|}{ Types of Question } & \multicolumn{1}{c|}{ Form Questions } \\
\hline Questions of clarification & $\begin{array}{l}\text { What do you mean by...? } \\
\text { What is your main opinion? } \\
\text { Can you give an example? } \\
\text { Do you think the main issue is here? }\end{array}$ \\
\hline $\begin{array}{l}\text { Questions that investigate } \\
\text { assumptions }\end{array}$ & $\begin{array}{l}\text { What do you assume? } \\
\text { How do you account for this? } \\
\text { Is this a case? }\end{array}$ \\
\hline $\begin{array}{l}\text { Questions that investigate reasons } \\
\text { and evidence }\end{array}$ & $\begin{array}{l}\text { What are examples? } \\
\text { Can you explain the reason to me? } \\
\text { Is the reason that you say enough? }\end{array}$ \\
\hline $\begin{array}{l}\text { Questions about perspective } \\
\text { opinion }\end{array}$ & $\begin{array}{l}\text { How do other groups respond? Why? } \\
\text { How to answer the objection that } \\
\text { happened? } \\
\text { How do you know the other way? }\end{array}$ \\
\hline $\begin{array}{l}\text { Questions that investigate } \\
\text { implicatively as a result }\end{array}$ & $\begin{array}{l}\text { What implications do you make? } \\
\text { What will happen? } \\
\text { What is the alternative? } \\
\text { If this is a case then what else must be } \\
\text { true? }\end{array}$ \\
\hline Questions about questions & $\begin{array}{l}\text { How can we find out? } \\
\text { Can we explain this question? } \\
\text { What does this question assume? } \\
\text { Why is this question important? }\end{array}$ \\
\hline
\end{tabular}

The use of Socrates' questions has gained the support of evidence from the results of empiric studies. Ref. [5] [6] show that the Socrates dialogue method effectively develops students' critical thinking, and develops active motivation and class interactions.

Ref. [7] expressly stated that the Socrates question is closely related to the concept of critical thinking. Critical thinking is developed through a process system that shapes individual thoughts that focus on reasoning while Socrates questions can stimulate thinking through measurable questions. On the other hand, Ref. [8] states that Socrates dialogue can improve students' thinking skills because takes place through intellectual discussion and content-based learning, Ref. [9] also reveals Socrates' questions can raise questions that help develop critical thinking skills.

Based on the above results, the Socrates questions can stimulate critical thinking of pre service teacher students because the question form is more analytical and evaluative. The socrates questions in the process of learning specifically chemistry can be combined with chemical representation through the level of jonstone thinking to train creative thinking.

\section{B. Chemistry and Chemical Representation}

Chemical concepts are generally abstract, so they need to be comprehended comprehensively. Subsequent chemical concepts will be difficult to understand if the previous concept is not well mastered [10]. The abstractness of chemical concepts makes it difficult for students to study chemistry, as the results of Dickson's research [11], that with chemical abstracts the results of students tend to bring their own views about scientific phenomena and experiences they have had to chemical concepts.

Chemical material is generally between phenomenology and abstraction, macroscopic and microscopic, which means that in understanding macroscopic understanding microscopy also. To bridge between phenomenology and abstraction, the experts use several representations which are then known as chemical representations. Chemical representations have a number of meanings; giving a depiction (to depict as), recalling the mind through image or imagination (to call in or portrayal or imagination), and symbolizing (to symbolize) [12][13]. The meaning of these terms reinforces the importance of a representation to help describe and symbolize in an explanation. Chemical representation is explained through the Level of Thinking Theory of Jonstone [14]. Chemical representation based on a macro, symbolic and submicron is very important to be taught to pre service chemistry teacher considering the condition that most of the pre service chemistry teachers can explain the concept macroscopically, but are unable to explain on the microscopic scale. It can affect high-level thinking (High Order Thinking) such as critical and creative thinking which is demanded for 21st-century learning.

The level of thinking put forward by Jonstone [14] consists of macro, submicro, and symbolic levels. These three aspects can be explained in triangle diagram in Figure 1.

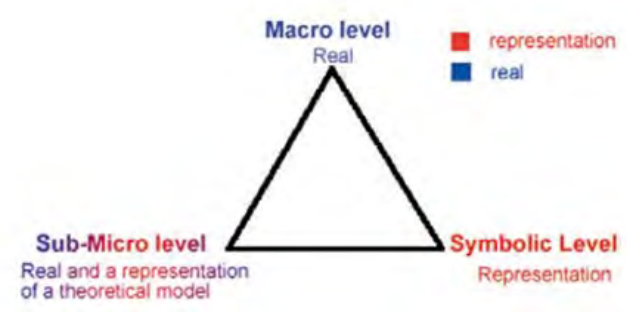

Fig. 1. Level of thinking Jonstone 
Macroscopic aspects (observable phenomena) are described chemical representations obtained through real observation of a phenomenon that can be seen and perceived by the five senses both directly and indirectly, microscopic aspects are chemical representations that explain and expand the structure and process at the level particular (phenomenon at the molecular or atomic level, ion) to the macroscopic phenomena observed. The representation model at this level can be expressed starting from the simple to using computer technology, which is using words, diagrams/images, twodimensional models, three-dimensional models both silent and moving as multi-representation. Symbolic representations are chemical representations qualitatively and quantitatively, namely chemical formulas, diagrams, images, reaction equations, stoichiometry, and mathematical calculations [12][15].

On the other hand, Johnstone reveals in the writings of [10][16], the relevance of triplet relations in chemistry education is at least three different levels. Those levels are (1) descriptive and functional is the rate at which phenomena experienced, observed, and explained, (2) representation is the level at which signs are used to represent and communicate about concepts and ideas, and (3) explanation is the rate at which phenomena are explained in light of certain chemical properties. Johnstone builds strong relationships between the levels of "descriptive and functional" called with macrochemistry.

One of the alternative solutions to the above problems in the learning process is demanded that there are comprehensive teaching materials in order to stimulate creative-critical thinking. Comprehensive teaching materials, namely teaching materials that can combine questions of socrates and chemical representations. Based on the study, socrates questions and chemical representations can stimulate creative-critical thinking with conditions that are implemented comprehensively in the learning process. Chemical representations are related to the concept of chemical bonds, molecular forms and solvation processes that require complex thinking or high-level thinking. Representation is inseparable from visualization. Visualization according to Ref. [17][18], can activate the right hemisphere which is the realm of creative thinking because it is related to imagination. Based on observations in the field, generally, chemical books explain the concept of chemistry more towards symbolic than submicro so that teaching materials are needed that not only involve macro and symbolic but also submicros, for example, salt dissolution process or chemical reaction for example in Figure 2 and Figure 3.

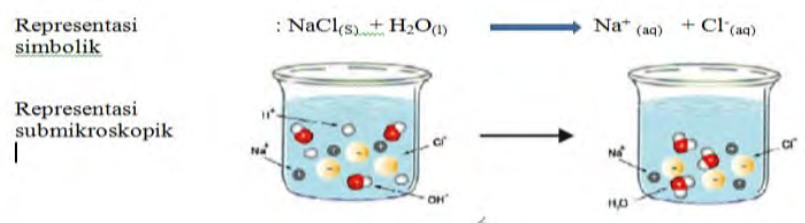

Fig. 2. Dissolution of salt representation

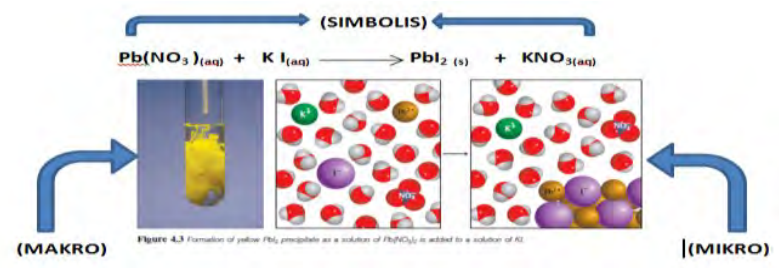

Fig. 3. Chemical reaction representation

Comprehensive chemical representation in addition to visualization in its presentation takes into account the concept of bonding, molecular shape and the concept of dissolution. The role of the three levels of chemical phenomena in learning must receive attention so that students experience ease in transferring knowledge through the interconnection between one level to another. Conceptual knowledge is one of the essential parts that students must possess.

Studying chemistry with representation can help the storage process in long-term memory. Students must be encouraged to use their mental models in connecting the three levels of the chemical phenomenon. On the other hand Ainsworth in Ref. [19], states that what representation is expressed by [14][15][20] can function as an instrument that gives shamans supported by comprehensive chemical concepts such as the concept of chemical action, molecular shape and solvation process so that it does not cause misconceptions. This condition is supported by Ref. [21][22], research that representation ability is not necessarily innate, but it is a skill that can be learned through instruction and practice.

\section{CONCLUSION}

Based on the above explanation of the chemical material taught, using socrates questions and comprehensive chemical representation stimulates the pre service chemistry teacher's critical thinking - creative. It also helps the pre service teachers to understand chemistry more deeply on the condition that the representation meets the rules of the concept of chemical bonds and forms molecules and solvation processes so that they do not cause new problems such as misconceptions.

\section{REFERENCES}

[1] A. S. R. Alghafri, H. N. B. Nizam, "The effects of integrating creative and critical thinking In schools students' thinking," International Journal of Social Science and Humanity, vol. 4, no.6, pp. 518-525, 2014.

[2] P. A. Facione, "Critical Thinking: What It is and Why It Counts," 2011. [Online]. Available: https://www.nyack.edu/files/CT_What_Why_2013.pdf.

[3] R. Chang, Chemistry, 10th ed., United States: McGrawHill Companies, 2010.

[4] R. Paul, A. J. A. Binker, D. Martin, C. Vetrano, Critical Thinking Handbook $6^{\text {th }}-9^{\text {th }}$ Grade: A Guide for Remodelling Lesson Plans in Language Arts, Social Studies, and Science. California: Foundation for Critical Thinking, 1989. 
[5] K. Koellner-Clark, L. L. Stallings, S. A. Hoover, "Socratic seminars for mathematics," Mathmatic Teacher, vol. 95, no. 9, pp. 682-687, 2002.

[6] M. Hajhosseiny, "The effect of dialogic teaching on students' critical thinking disposition," Procedia-Social Behavioral Sciences, vol. 69, pp. 1358-1368, 2012.

[7] R. W. Paul, L. Elder, Critical Thinking: Tools For Taking Charge of Your Learning and Your Life. Upper Saddle River. London: Pearson, 2011.

[8] R. Collins, "Skills for the 21st Century: teaching higher-order thingking," Curriculum \& Leadership Journal, vol. 12, no. 14, 2014.

A. G. Picciano, "Blending with purpose: the multimodal model," Journal of Research Center for Educational Technology, vol. 5, no.1, pp. 4-14, 2009.

[10] V. Talanquer, "Macro, Submicro, and Symbolic: The many faces of the chemistry "triplet"," International Journal of Science Education, vol. 33, no. 2, pp. 179195, 2011.

[11] H. Dicson, C. D. Thomson, P. O. Toole, "A picture is worth a thousand words: investigating first year chemistry students' ability to visually express their understanding of chemistry concepts," International Journal of Innovation in Science and Mathematics Education, vol. 24, no. 1, pp.12-23, 2016.

[12] J. K. Gilbert, D. Treagust, Multiple Representations in Chemical Education. Berlin: Springer Science+Business Media, 2009.

[13] R. Kozma, J. Russell, "Students becoming chemists: developing representational competence," in Visualization in Science Education, J. Gilbert, Eds. Berlin: Springer, 2005.
[14] A. H. Johnstone, "Chemical education research in Glasgow in perspective," Chemical Education Research and Practice, vol. 7, no.2, pp. 49-63, 2006.

[15] S. M. Al-Balushi, "The effect of different textual narrations on students' explanations at the submicroscopic level in chemistry," Eurasia Journal of Mathematics, Science \& Technology Education, vol. 9, no. 1, pp. 3-10, 2013.

[16] S. T. Levy, E. U. Wilensky, "Crossing levels and representations: the connected chemistry (CC1) curriculum," Journal of Science Education and Technology, vol. 18, no. 3, pp. 224-242, 2009.

[17] E. Jensen, Brain Base Learning The New Paradigm of Teaching $2^{\text {nd }}$ ed. California: ASAGE Company, 2008.

[18] D. A. Sousa, How the Brain Learns 4th ed. California: A SAGE Company, 2011.

[19] D. F. Treagust, R. Duit, "Conceptual change: A discussion of theoretical, methodological and practical challenges for science education," Cultural Studies of Science Education, vol. 3, pp. 297-328, 2008.

[20] Y. I. Lin, J. Y. Son, J. A. Rudd, (2016), “Asymmetric translation between multiple representations in chemistry," International Journal of Science Education, vol. 38, no.4, pp. 644-662, 2016.

[21] G. Chittleborough, D. F. Treagust, "The modelling ability of non-major chemistry students and their understanding of the sub-microscopic level," Chemistry Education Research and Practice, vol. 8, no.3, pp. 274-292, 2007.

[22] B. Y. Guzel, E. Adadan, "Use of multiple representations in developing preservice chemistry teachers' understanding of the structure of matter," International Journal of Environmental \& Science Education, vol.8, no. 1, pp. 109-130, 2013. 